whistleblower in the case a rotten time. Where have been the academies and the learned societies during all the fuss? Where are they now, when the most urgent need is for a speedy conclusion to a still-corrosive issue? Complaints abound that Dingell is a bully, but do not the academies and societies understand that the role of the US Congress in policing the manners of the research community is partly a measure of their own neglect?

Baltimore himself now deserves the respite from controversy for which he asked last week, on behalf of his family especially. So, too, does the Rockefeller University, the vacillations of its trustees and faculty in the past few weeks notwithstanding. The best outcome would be what Baltimore hopes for himself - a return to research, perhaps in AIDS. There is nothing like creative work to chase bitterness away. It would help to that end if the Dingell Committee would quickly clear up the issues outstanding from the 1989 hearings. And those tempted to ask whether the punishment fits the crime should remember that there is no crime, but a gross error of judgement magnified by obstinacy into a public scandal and that there is hardly a punishment more severe than having to resign as leader of the institution at which one began a research career such as Baltimore's.

\section{Poor rich Japan}

There is little merit in US demands that Japan should contribute to the new accelerator in Texas.

PooR rich Japan! For the past several months, a succession of visitors from the United States have been in Tokyo pleading for what in other contexts is called technical assistance (and which may often consist of mere money) with the construction of the Superconducting Super Collider (SSC) now being built in Texas. Last week (see page 424), it was Admiral James Watkins, the Secretary of Energy. Next month, President George Bush, on a delayed visit, will raise the issue. The United States is looking for about $\$ 1,000$ million, in cash or in kind. Japanese officials have always made it plain that their government will say "Yes!" only to the US President himself. But, in everybody's interests, they should be steeling themselves to say "No!".

Not that international collaboration on accelerators at the frontiers of high-energy physics is a bad thing. On the contrary, as experience in Europe has shown, only collaboration can allow any but the richest parts of the research enterprise to build their own machines. Even in the United States, the high-energy physics community acknowledges that the time must come when joint construction will be unavoidable. But when? For decades, the received opinion has been that international collaboration will be indispensable for the accelerator after next.

What is being offered to Japan is not, in reality, collaboration, but an opportunity to contribute to a machine already fully designed and whose components are mostly fully developed. The argument that Japan would thereby be placed at the frontiers of accelerator technology is mistaken; the mere replication of components already designed is no substitute for the execution of an advanced design. In return, Japanese physicists would presumably have access some of the data from the detectors, in the design of which some of them have had a hand. But that makes light of the boast in high-energy physics that hospitality at one another's machines is habitual.

But should not Japan be investing more in basic research? That is what the United States is also urging. Most Japanese would agree - and would point to the figures in the current research budget showing buoyant spending on basic research at universities and research institutes. Spending $\$ 1,000$ million on a machine in Texas will not advance that cause, but will, if anything, impede it. Even in rich Japan, the money would have to come from somewhere. And the consequences of that could be unfortunate. $\mathrm{Al}$ ready, resentment in Japan at what is bound to seem an attempt to dictate the pattern of another's research budget is too palpable for comfort.

\section{Nature's Macmillan}

Alive, Robert Maxwell embarrassed many, but the aftermath of his death is peripherally embarrassing for Nature.

THE dramatic collapse last week of the late Mr Robert Maxwell's publishing organization is a general embarrassment and also, strange as it may seem, for this journal. The difficulty is that Maxwell's Maxwell Communications Corporation owns a publishing company in the United States called "Macmillan" which is easily mistaken for the British publishing company of the same name, which happens to own Nature (which it founded).

Until after the Second World War, the US company was a subsidiary of the British. Before publishing became an international business, the British company sold its US subsidiary, with the understanding that the newly independent company could use the name "Macmillan" only in the United States; the British company retained that same right elsewhere in the world. (The British company afterwards set up a new subsidiary in the United States, which is now the successful St Martin's Press of New York, but Nature's interests in the United States are managed by Nature Publishing Co. Inc., also of New York.) Until quite recently, the two companies coexisted amicably, despite the inconvenience of apparent identity.

Maxwell's purchase of US Macmillan (the cost of which, at $\$ 1,300$ million, appears to have helped push his companies into insolvency) changed that. The US company became careless about the covenants restricting its use of the common name, and Maxwell adopted a logo resembling that of the British company. Legal suits are said to have been multiplying. This journal's concern is that confusion over the common name should not lead subscribers or advertisers to conclude that we are on shaky ground. Our owners say they are both solvent and profitable. Moreover, the company's pension fund is intact. 